\title{
Potential Utilization of Dairy Cattle Waste into Biogas (Jetak Village, Semarang City, Central Java)
}

\author{
Andhina Putri ${ }^{1,4^{*}}, P . P u r w a n t 0^{1,2}$ and Hartuti Purnaweni ${ }^{1,3}$ \\ ${ }^{1}$ Doctoral Program of Environmental Science, School of Postgraduate Studies, Diponegoro University, Semarang, Indonesia \\ ${ }^{2}$ Faculty of Chemical Engineering, Diponegoro University, Semarang, Indonesia \\ ${ }^{3}$ Faculty of Social Science and Political Science, Diponegoro University, Semarang, Indonesia \\ ${ }^{4}$ Faculty of mathematics and natural science, Universitas Negeri Semarang, Indonesia
}

\begin{abstract}
This study aims to identify the potential of dairy cattle waste to become biogas in Jetak Village as a solution in dealing with environmental problems. In this study using primary data obtained from 72 respondents through in-depth interviews, observation and documentation. The method used is descriptive qualitative with a qualitative descriptive approach and an analysis of conversion of dairy cattle dung into methane gas production. The results showed that the potential for renewable energy from dairy cattle waste to biogas was $4,424 \mathrm{~kg} /$ day or equivalent to $35.35 \mathrm{~m} 3 / \mathrm{kg}$ with a methane content of $24.75 \mathrm{~m} 3$. The utilization of dairy cattle waste in Jetak Village into compost / organic fertilizer has not been done by the community due to a lack of community knowledge and the motivation of people who are still low in processing livestock waste into other products.
\end{abstract}

Keywords: dairy cows; waste; potential; biogas; fertilizer.

\section{Introduction}

The share of eventual energy consumption in Indonesia is command by oil, shadow by gas, coal and hydro energy. Petroleum products and oil imports will increase to meet growing domestic demand. Increasing energy consumption growth will make Indonesia a pure oil importer if there are no new energy resources and energy efficiency efforts from both the Government and society [1].

Indonesia is a time to reduce dependence on fuel oil by developing alternative energy sources that are renewable and environmentally friendly. One type of alternative fuel is bioenergy. Bioenergy can be used continuously because of the raw material for making it is quite guaranteed. In addition, bioenergy has properties that are environmentally friendly, easily biodegradable and able to reduce the greenhouse effect [2].

A simple way to get bioenergy raw materials is to utilize organic waste around humans and cultivate biofuelproducing plants. Indonesia is one country that has vast land resources in sufficient cultivation of plants and biofuel-producing livestock [2].

One form of bioenergy that is developed in rural areas, namely biogas. The basic principle of making biogas is the process of organic materials described microorganisms in conditions without air (anaerobic) to produce various gases, namely methane and carbon dioxide [3]. The livestock sector, especially dairy cattle, is one of the high potential businesses in developing alternative energy, especially biogas energy. This is supported by the potential for waste produced by very high dairy farms compared to other farms. Dairy cow manure produces the highest calorific value and good dairy cow waste management can reduce environmental pollution [4].

Most of the people of Jetak Village work as graziers and cattle farmers. The average dairy cow owned by the people of Jetak village is 3-5 cows/kk. Therefore Jetak village is an area has the capability of raw materials in the supply of renewable energy sourced from cattle waste. This is supported by the comparative advantage of Jetak Village in the development of cattle business which can be seen from the adequate carrying capacity of land and livestock populations that are scattered in all areas of the Village with a population of 158 dairy cattle [5]. With the total dairy cattle population, Jetak Village has the potential to produce renewable energy from dairy cattle waste to support the Government in an energy-independent village program.

\footnotetext{
*Corresponding author: andhinaputri86 $@$ yahoo.co.id
} 


\section{Method}

This research was conducted in Jetak Village, Getasan District, Central Java. Location selection is done purposively because Jetak Village is one of the centers of dairy farming in Getasan District which has the potential of livestock waste in producing renewable energy. The study was conducted on people who have dairy cattle. The research was conducted from April to May 2017.

The population in this study is the people who have dairy cows located in Jetak Village, Getasan District. The technique of determining the sample in this study was conducted by purposive sampling, which is to choose anyone who carries out cattle grazing routinely, who fulfills the requirements to be sampled with the consideration that the respondent routinely manages cattle [6].

The variables used in this study are the number of population dairy cattle, utilization of dairy cattle waste, potential biogas raw materials from livestock, the amount of livestock waste produced by farmers and the amount of potential renewable energy. Based on the results of verification of the number of respondents in the field, the number of respondents was 72 families. To complete the primary data needed from the society, the users of biogas energy at the research location were conducted interviews, observations, and documentation. The design used is definitive qualitative with a qualitative descriptive approach and an analysis of the conversion of dairy cattle dung into methane gas production.

\section{Result and Discussion}

Jetak Village is one of the villages in Semarang Regency and most of the people work as farmers. Jetak Village is directly adjacent to Salatiga and Boyolali. The land area in Jetak Village is used as a dry agricultural land of community forests and moor by surrounding communities. In supporting the availability of dairy cattle, the community also utilizes the available plantation and agricultural land around them. Jetak Village is a mountainous area that has the carrying capacity of fertile soil, suitable climatic conditions.

The topography of Desa Jetak is plain with coordinates of latitude 7.3915 and longitude 110.4814 . The percentage of the area of Jetak Village is $4.47 \%$ with an area of 2.94 $\mathrm{km} 2$. Geographically within $\pm 35 \mathrm{~km}$ from the Capital of the Regency is above sea level $\pm 850 \mathrm{~m}$ with an air scale between $18-26^{\circ} \mathrm{C}$. Jetak Village has 12 hamlets, $12 \mathrm{RWs}$ and 33 RTs.

Capital is very important in the development of dairy cattle populations and increasing additional income, namely the level of dairy cattle ownership by ranchers. Jetak Village has 12 hamlets where the largest number of cattle ownership is in the Legok 1hamlet with 20 dairy cows. Meanwhile, the smallest number of cattle ownership is in Weru B hamlet with 9 dairy cows. Overall the number of dairy cows owned by respondents in Jetak Village is 158 individuals. The data can be seen in Table 1 .

Table 1. Data on Population of Dairy Cows in Jetak Village

\begin{tabular}{|c|c|c|}
\hline No & Sub Village & Population \\
\hline 1 & Setugur & 15 cows \\
\hline 2 & Jayan & 14 cows \\
\hline 3 & Dukuh & 12 cows \\
\hline 4 & Tosoro B & 11 cows \\
\hline 5 & Tosoro A & 12 cows \\
\hline 6 & Weru A & 13 cows \\
\hline 7 & Weru B & 9 cows \\
\hline 8 & Kemiri & 11 cows \\
\hline 9 & Legok & 20 cows \\
\hline 10 & Kendal cows \\
\hline 11 & Gajian & 14 cows \\
\hline 12 & Jetak & 11 cows \\
\hline & Total & $\mathbf{1 5 8}$ \\
\hline
\end{tabular}

When viewed from the number of dairy cows in Jetak Village, the amount of livestock waste produced by these animals can be calculated every day. The more livestock waste produced, the greater the potential for its use to be renewable energy, namely the biogas energy is also getting bigger. Biogas energy is one of the bioenergy that is environmentally friendly and renewable. To conduct analysis and calculate the magnitude of the potential for renewable energy from cattle waste, it is necessary to know in advance the number of cattle ownership that is maintained intensively by the respondents, because there are adequate cages at the research location. The availability fraction of manure, which represents the amount of feedstock that could be actually collected, strongly depends on species current farming system and disposal practices. The average livestock density per holdings across Europe was assessed at the regional level and the number of animals per holding was combined in an availability indicator for manure collection. More intensive livestock farming, with higher livestock density, is more likely to be able to collect manure from the farm, which can be further used for biogas production [7].

In the development of biogas energy, if viewed from the livestock sector, it can provide added value for the farmers who use it. The farmers have only used meat, chicks, and milk produced by livestock that they maintain for their daily income from the livestock business. If viewed in terms of the benefits of sewage waste produced by livestock, it can also provide benefits in reducing production costs, especially energy use in the livestock business. This is in line with [8] utilization of livestock manure for biogas development, which can reduce farmer household costs, namely the cost of energy needs.

In Table 2, you can see Renewable energy raw material data from Dairy Cattle Waste in Jetak Village, Getasan District. Based on the processed data by referring to the 
existing cattle population in Jetak Village, the potential for biogas obtained from dairy cattle waste is $3,950.00 \mathrm{~kg} / \mathrm{day}$.

Table 2. Production of Stool, Gas Potential and Methan in Jetak Village, Getasan District

\begin{tabular}{|c|c|c|c|c|}
\hline No & $\begin{array}{c}\text { Sub } \\
\text { Village }\end{array}$ & $\begin{array}{l}\text { Manure } \\
\text { (kg/day) }\end{array}$ & $\begin{array}{c}\text { Potential } \\
\text { Gases } \\
\left(\mathrm{m}^{3} / \mathrm{kg}\right)\end{array}$ & $\begin{array}{c}\text { Contain } \\
\text { of } \\
\text { methane } \\
\left(\mathbf{m}^{3}\right)\end{array}$ \\
\hline 1 & Setugur & 375 & 3 & 2,1 \\
\hline 2 & Jayan & 350 & 2,8 & 2 \\
\hline 3 & Dukuh & 300 & 2,4 & 1,68 \\
\hline 4 & Tosoro B & 275 & 2,2 & 1,54 \\
\hline 5 & Tosoro A & 300 & 2,4 & 1,68 \\
\hline 6 & Weru A & 325 & 2,6 & 1,82 \\
\hline 7 & Weru B & 225 & 1,8 & 1,26 \\
\hline 8 & Kemiri & 275 & 2,2 & 1,54 \\
\hline 9 & Legok & 500 & 4 & 2,8 \\
\hline 10 & Kendal & 400 & 3,2 & 2,24 \\
\hline 11 & Gajian & 350 & 2,8 & 2 \\
\hline \multirow[t]{2}{*}{12} & Jetak & 275 & 2,2 & 1,54 \\
\hline & Total & 3950 & 31,6 & 22,2 \\
\hline
\end{tabular}

Equivalent to $31.6 \mathrm{~m} 3$ of gas with a methane content of $22.2 \mathrm{~m} 3$. Every $1 \mathrm{~m} 3$ of methane is equivalent to 0.46 $\mathrm{kg}$ of LPG, 0.62 liters of kerosene, 0.52 liters of diesel fuel, 0.80 liters of gasoline and $3.50 \mathrm{~kg}$ of fuelwood [9]. This cattle waste produced in Jetak Village is equivalent to $10.212 \mathrm{Kg}$ of $\mathrm{LPG}$, equivalent to 13.810 . Liters of kerosene, 11,544 liters of diesel fuel, 17,760 liters of gasoline and equivalent to $77,000 \mathrm{Kg}$ of firewood.

If viewed from the potential of sufficient raw materials to utilize renewable energy as a substitute for fossil fuels according to [10], this potential has not been utilized properly due to several factors including:

a. Damage at several points of biogas installation has not been repaired by biogas users so that the installation cannot be reused

b. The type of fixed dome installation that is built does not meet the standard so that it is not utilized

c. There are other energies use besides biogas so that biogas energy has not been fully utilized by biogas users

d. The motivation of the community to carry out maintenance and maintenance regularly is still low

With reference to ESDM Ministerial Regulation No.

10 of 2015 concerning technical guidelines for the use of the 2015 Special Allocation Fund for Rural Energy Sector, household scale measuring $1.5 \mathrm{M}$, with a diameter of 1.50 $\mathrm{M}$, then the contents of Biogas $612.30 \mathrm{Kg}$ (water and feces were obtained), with a ratio of $1: 1$, each household-scale container requires approximately $306.15 \mathrm{~kg}$ of feces.

Table 3. Distribution of Potential Development of Household Scale Concrete Biogas Installation according to ESDM Ministerial Regulation No. 10 of 2015

\begin{tabular}{|c|c|c|c|c|c|c|}
\hline No & Sub Village & Population & $\begin{array}{l}\text { Manure } \\
\text { (kg/day) }\end{array}$ & $\begin{array}{c}\text { Potential } \\
\text { Gases } \\
\left(\mathrm{m}^{3} / \mathrm{kg}\right)\end{array}$ & $\begin{array}{c}\text { Contain of } \\
\text { methane } \\
\left(\mathrm{m}^{3}\right)\end{array}$ & $\begin{array}{c}\text { Biogas } \\
\text { installation }\end{array}$ \\
\hline 1 & Setugur & 15 tail & 375 & 3 & 2,1 & 1 \\
\hline 2 & Jayan & 14 tail & 350 & 2,8 & 2 & 1 \\
\hline 3 & Dukuh & 12 tail & 300 & 2,4 & 1,68 & 1 \\
\hline 4 & Tosoro B & 11 tail & 275 & 2,2 & 1,54 & 1 \\
\hline 5 & Tosoro A & 12 tail & 300 & 2,4 & 1,68 & 1 \\
\hline 6 & Weru A & 13 tail & 325 & 2,6 & 1,82 & 1 \\
\hline 7 & Weru B & 9 tail & 225 & 1,8 & 1,26 & 1 \\
\hline 8 & Kemiri & 11 tail & 275 & 2,2 & 1,54 & 1 \\
\hline 9 & Legok & 20 tail & 500 & 4 & 2,8 & 2 \\
\hline 10 & Kendal & 16 tail & 400 & 3,2 & 2,24 & 1 \\
\hline 11 & Gajian & 14 tail & 350 & 2,8 & 2 & 1 \\
\hline \multirow[t]{2}{*}{12} & Jetak & 11 tail & 275 & 2,2 & 1,54 & 1 \\
\hline & Total & 158 & 3950 & 31,6 & 22,2 & 13 \\
\hline
\end{tabular}

In Jetak Village a 13-unit household-scale biogas installation can be built if it refers to the number of renewable energy potential with the basic waste of dairy cattle. In Table 3 illustrates the distribution of potential biogas installations as renewable alternative energy that can be built in Jetak Village, Getasan District.

In choosing the type of installation to be built according to the characteristics of the community of biogas users and the location of the installation. The fixed dome model is built in the ground with raw materials of cement, sand, stone, and brick. The design is made airtight and the structure must be strong to withstand gas leaks. The advantages of a fixed dome model digester are easier maintenance and lower costs. The disadvantage is that it takes a long time in the manufacturing process, is prone to cracking, cannot be moved and construction costs are quite expensive. The pores in the digester are large enough to cause the gas produced to easily leak, making it difficult 
to do early detection and repair [11]. The quality and volume of biogas production from animal waste using the $\mathrm{AD}$ process is highly affected by several parameters such as the design of the biodigester reactor type of raw material, temperature, $\mathrm{pH}$, and presence of other nutrients or substances. In general, two types of reactors commonly used for biogas production; fixed dome reactor (Chinese) model and floating dome reactor (Indian) model. the former design is often preferred for both small- and largescale production as it is considered easy to build and modify inexpensive, and able to produce more biogas [12]. Adequate facilities and infrastructure one of the supporting aspects of supporting biogas applications in Jetak Village, Getasan District.

\section{Conclusion}

The waste of cattle (feces) in Jetak Village, Getasan Subdistrict has not been utilized because of the lack of knowledge possessed by these farmers to utilize cattle waste to become renewable energy. The potential for renewable energy from cattle waste is $3,950 \mathrm{~kg}$ feces/day, equivalent to $31,600 \mathrm{~m} 3$ of gas with a methane content of $22,200 \mathrm{~m} 3$. In Jetak Village a 13-unit household-scale biogas installation can be built. In choosing the type of installation to be built according to the characteristics of the community of biogas users and the location of the installation.

\section{References}

1. R. Sitompul, Teknologi Energi Terbarukan yang Tepat untuk Aplikasi di Masyarakat Pedesaan, Jakarta : PNPM Support Facility (PSF) (2011)

2. T. Mentari, Partisipasi Masyarakat dalam Program Desa Mandiri Energi di Desa Kujau Kecamatan
Betayu Kabupaten Tana Tidung (Studi Kasus Kelompok Tani Ternak Mandiri di Desa Kujau Kecamatan Betayau Kabupaten Tana Tidung), eJournal Ilmu Pemerintahan ISSN 2338-3651 (2014)

3. S. Wahyuni, Biogas Energi Terbarukan Ramah Lingkungan dan Berkelanjutan, Kongres Ilmu Pengetahuan Nasional ke-10 : Jakarta (2011)

4. R. Nurmalina, S. Riesti, Analisis Biaya Manfaat Pengusahaan Sapi Perah dan Limbah Untuk Menghasilkan Biogas pada Kondisi Risiko (Studi Kasus: Kecamatan Cisarua dan Megamendung, Kabupaten Bogor, Jawa Barat), Jurnal Pertanian ISSN 2087-4936 1(1) (2010)

5. BPS Kabupaten Semarang

6. Sugiyono, Metode Penelitian Kombinasi (Mixed Methods), Alfabeta. Bandung (2012)

7. S. Nicolae, F. Fernando, J.F. Dallemand, M. Fabio, M. Vicenzo, A spatial analysis of biogas potential from manure in Europe, Sciencedirect (2017)

8. S.A. Aku, N. Sandiah, M.A. Pagala, D. Zulkarnain, W. Ahmad, Penyusunan Data Base Pemanfaatan Limbah Ternak Sebagai Sumber Energi Terbarukan Di Sulawesi Tenggara, Kendari (2015)

9. Salundik, Biogas Teori: Materi Magang Biogas, IPB. Bogor (2008)

10. A. Putri, et al., Evaluation of Livestock Waste Management to Energy Biogas (Case Study: Jetak Village, Getasan Sub District), E3S Web of Conference 73,07013 (2018)

11. S. Wahyuni, Biogas, Depok : Penebar Swadaya (2008)

12. K. Munawar, M.A. Berawib, H. Rudi, R. Akhmad, Waste to energy technology:The potential of sustainable biogas production from animal waste in Indonesia, Sciencedirect (2018) 